\title{
Hérib Campos Cervera, poeta de la muerte
}

S en el Paraguay existiera una pléyade de poetas de la estatura de Rubén Darío o de Pablo Neruda, América no lo sabría. Esa nación irreductible en su voluntad de independencia -independencia que aseguró con largos lustros de enclaustramiento-, parece condenada a que su mediterraneidad geográfica la sitúe indefinidamente fuera del mapa espiritual del Continente. Los tratados de literatura y las antologías hispanoamericanas rara vez incluyen autores paraguayos. Pero eso no significa que ellos no existan. Significa, sí, que se los ignora. $Y$ sin embargo hay prosadores y poetas paraguayos que merecen un lugar honroso en aquellos tratados $y$ en aquellas ántologías. Uno de ellos es, por ejemplo, Hérib Campos Cervera, poeta verdadero, hijo y nieto de escritores. ${ }^{1}$

PoÉTICA Y POESÍA

Conforme a su idea fundamental de la creación poética, Hérib Campos Cervera es superrealista hasta la médula de los huesos. Postula él un automatismo psíquico en virtud del cual ha de efectuarse una fidelísima captación de los procesos psíquicos prescindiendo de toda intervención del intelecto. La mente debe permanecer en un estado de pasividad y receptibilidad tal, que la reflexión no pueda ejercer desviación alguna en la fluencia libérrima de sus fantasmagorías. En teoría, pues, Campos Cervera asume una actitud idéntica a la preconizada por André Breton: escribir poesía es apresar, bajo los puntos de la pluma, cualesquiera imágenes, ideas, ocurrencias que se realicen en la mente del poeta. ${ }^{2}$ 
Esta concepción impone un absoluto respeto hacia la vivencia "en bruto", ya que en ella residen los verdaderos valores poéticos.

Sólo tras una sonambúlica exploración de la vida inconsciente, es posible descubrir la castalia auténtica superrealista.

En Campos Cervera, felizmente, esta posición es solamente teórica. En la práctica el poeta se manifiesta un escrupuloso artífice. Sus mejores poemas revelan precisamente lo contrario de una pasiva receptividad psíquica que vuelque, automáticamente, sus figuraciones sobre el papel. "El hachero" o "El sembrador" -que serán comentados más abajo-, evidencian un cuidadoso proceso selectivo, un reiterado volver sobre lo escrito para purificarlo, para pulirlo. La tan vilipendiada raison de los surréalistes interviene en ellos no para imponer rígidos esquemas conceptuales, sino para seleccionar críticamente las cristalizaciones del sentimiento. En esos poemas se advierte que ha habido una consciente elección del tema, un desarrollo coherente y un desenlace armónico. No se cumplen en ellos las instrucciones inequívocas de Breton, según las cuales se ha de comenzar a escribir rápidamente, sin previa elección de tema y sin releer lo ya escrito. ${ }^{3}$

Ahora bien, ¿' es Campos Cervera, rigurosamente hablando, un poeta superrrealista? La respuesta es afirmativa no sólo porque el término surréalisme sea amplio y elástico, sino porque abunda en su poesía la imaginería irracional, onírica, de la escuela, con su falta de "lógica" en las comparaciones y la obscuridad en las alusiones. Respiramos en esta poesía una atmósfera semejante a la de la de Aleixandre y a la de Neruda, bien que la temática de Campos sea más reducida y hasta su versificación más regular, más ceñida al alejandrino.

Además $-\mathrm{y}$ esto no carece de importancia-, Campos Cervera es superrealista en su más radical postura vital: lo es en la vida cotidiana, en los negocios, en la conversación confidencial, en la correspondencia. ${ }^{4} \mathrm{El}$ poeta muestra especial predilección por las ideas más raras, por los incidentes más insólitos, por las anécdotas que, contadas por él, recuerdan cuadros de Oscar Domínguez o de Giorgio de Chirico. Claro que no siempre Campos Cervera habla en serio, $y$ lo que dice hay que tomarlo a veces con un grano de sal; pero 
aun así, su mismo humour es radicalmente superrealista. Lo cual no quiere decir que el poeta sea de ningún modo afectado o insincero. Todo lo contrario: en él, la actitud aludida es espontánea y natural, y, en esa espontaneidad y naturalidad de su actitud reside precisamente la esencia de su radical superrealismo.

En una carta, poética y brillante como todas las suyas, describe Campos Cervera una entrevista que tuvo en Buenos Aires con Juan Ramón Jiménez. En el último párrafo manifiesta que está muy contento de haber entrado en conocimiento del poeta andaluz, "de su persona, de su barba y de su projimidad." 5 Así escribe espontáneamente Campos Cervera, como si la barba juanramoniana, asumiendo entidad independiente, se hubiera desprendido de su dueño para ponerse a dialogar con nuestro poeta...

Hoy Campos Cervera vive en Buenos Aires desde 1947, por segunda vez desterrado, - la primera vez, hace unos veinte años, residió en Montevideo-. E1 primero y el segundo destierro han sido fecundos para nuestro poeta. Cuando muy joven por primera vez se vió obligado a abandonar su patria, vivió en Montevideo una vida literaria intensa y se le reveló en esa ciudad el espíritu de la nueva poesía. A su regreso al Paraguay, años después, se convertiría en líder indiscutido de un movimiento de renovación poética. ${ }^{6}$

Ahora, en la Argentina, puede ejercer su profesión, la agrimensura - Campos Cervera ha seguido la carrera de ingeniero-, y cuenta con amistades literarias valiosas, como la de Rafael Alberti, cuya tertulia frecuenta. Desterrado, el poeta ha ganado gran prestigio entre sus compañeros de exilio, pues, como se indicará más abajo, se constituyó en el más inspirado intérprete de todos ellos. Poemas suyos fueron calurosamente aplaudidos en casa de Alberti, por un auditorio selecto. Dos de sus discípulos predilectos le acompañan en el destierro. ${ }^{7}$

También en Buenos Aires, en los días de su primera expatriación, trabó amistad con Francisco Romero, a quien debe una valiosísima orientación en filosofía, disciplina de que el poeta ha sido años más tarde profesor, $\mathrm{y}$ cuyo estudio no ha abandonado nunca. $\mathrm{Y}$ ahora, en el destierro, se ha decidido por fin a publicar su primer libro, inspirado éste, en gran parte, por la nostalgia del terruño. 
Campos Cervera vive su apasionada existencia torturado por una angustia kierkegaardiana, consciente a toda hora de ser un Sein zum Tode, un ser para la muerte, según la expresión de Heidegger, no consolado por la afirmación de su maestro Francisco Romero, para quien el hombre no es ser para la muerte sino ser para el valor. Según Campos Cervera la poesía sólo brota del hontanar de la angustia, ya sea ésta la angustia personal del creador, ya la angustia compartida del prójimo, de que el poeta se hace generoso intérprete. De aquí las dos clases de poesía que Campos Cervera ha llamado poesía "de la máscara" y poesía "de projimidad" o del grito.

La primera es confesión personalísima del poeta, el cual se libera de sus íntimas congojas por los cauces del verso. La segunda es poesía altruista, "de servicio", y apunta a los fines sociales del arte. Es interpretación de la angustia de aquellos que, sufriendo en silencio, tienen la boca sellada para el grito o para el canto. Por eso ésta se llama poesía de projimidad. (La palabra projimidad la oyó Campos Cervera en labios de una campesina enlutada que velaba el cadáver de un deudo, y significa humanidad, caridad, compasión por el dolor del prójimo.) ${ }^{8}$

"No hay, no puede haber belleza inútil" - dice Campos Cervera-; "la poesía como expresión de la vida personal sirve como confesión libertadora de la angustia; la poesía del grito -o de projimidad-, sirve a los fines sociales del arte." 9

Uno de los libros favoritos de Campos es un pequeño volumen de Rainer María Rilke: Cartas a un joven poeta. En él ha identificado con entusiasmo sus propias ideas sobre la creación poética. ${ }^{10}$

\section{LA VISIÓN DEL MUNDO}

En la obra de Campos Cervera hay una ausencia total de alegría. No hay siquiera un entusiasmo fugaz por las cosas o los seres bellos y luminosos. Es un paisaje gris, sombrío y desolado el de esta poesía llena de angustia y desamparo, sin árboles verdes, sin cielos claros y sin pájaros jocundos.

Se insiste en esta poesía sobre los elementos a que se reducen los seres y las cosas, tras la destrucción y la muerte: la cal, la sal, la ceniza. Todos los poemas cerverianos parecen concebidos en mo- 
mentos de lúgubre melancolía, de fatal desolación. Hay en ellos algo radicalmente macabro y luctuoso, un dolor, una angustia metafísica irremediable. $Y$ es que el poeta ya anticipa en sus huesos, ya siente en ellos la sequedad de la cal pulverizada; en su carne ya presiente la aridez de la ceniza y en su espíritu lleva, a toda hora, la sombra de la muerte. La sal, palabra simbólica que suena en casi todos sus poemas, alude al dolor humano inevitable, al llanto con que fué amasado nuestro barro. Los pájaros mismos, cuando cruzan por sobre el páramo reseco de la poesía cerveriana, no cantan nunca: están mudos, o lloran, o realizan un rito fúnebre:

$$
\begin{aligned}
& \text { Alto, una cruz de pájaros en vuelo } \\
& \text { muestra el sitio del crimen ... } \\
& \text { ("Tránsito de la gacela") } \\
& \text { Te lloran cuatro pájaros; } \\
& \text { un agobio de niños y de títeres ... } \\
& \text { ("Pequeña letanía en voz baja") } \\
& \text { Los pájaros ya no tienen } \\
& \text { donde colgar sus canciones ... } \\
& \text { ("Balada para los árboles ausentes") }
\end{aligned}
$$

El mundo, en suma, se nos aparece en la visión cerveriana como una negación de las apariencias brillantes que revisten los seres bellos. La realidad radical, única y verdadera, es el dolor, el desamparo, la muerte. Vivir es, primariamente para Campos Cervera, ir muriendo; asistir angustiosamente al proceso ineluctable del propio anonadamiento. Vivir es llevar una cruz dentro de la carne sufridora, una cruz de cal - "la cruz del hombro"-, formada por nuestros huesos condenados al polvo.

De aquí que nada pueda hacer sonreír al poeta en un universo que es inmenso teatro de la muerte, y de aquí esa referida insistencia sobre los elementos últimos en que acaba el drama humano sobre el planeta. Aun la visión del cielo estrellado se presenta a sus ojos privada de su exaltadora hermosura: el mismo cielo de fray Luis, "de innumerables luces adornado", no ofrece a Campos Cervera otro espectáculo que el "del vasto cementerio de Dios". ${ }^{11}$

Un sentimiento tan trágico de la vida forzosamente había de llevarlo a la elegía, a la lamentación, al réquiem. Y sus mejores poemas son eso: elegías, lamentaciones in memoriam. Sólo hay en este 
mundo terrible y desolado que habita el poeta una única posibilidad de redención: el amor -la projimidad-, y el arte. El arte cuando se inspira en el amor doloroso por el humano dolor. De aquí que Campos Cervera llame a su primer libro de poemas Ceniza redimida. ${ }^{12}$

\section{El POETA EN BUSCA DE SU VOZ}

Hérib Campos Cervera publicó sus primeros versos el año 1923, en la revista Ariel, cuando florecía en el Paraguay un modernismo tardío. ${ }^{13}$ Vivía aún Alejandro Guanes que en aquel entonces retunía unos ensayos maeterlinckianos para formar con ellos el tomo de $\mathrm{Del}$ viejo saber olvidado. Pero con él se extinguiría dos años más tarde la voz más profunda que halló el modernismo en el Paraguay. ${ }^{14}$

El despertar de Campos Cervera a la poesía nueva ocurrió hace unos veinte años, cuando desterrado en Montevideo, como ya se ha dicho, se puso al día con las últimas novedades literarias. En Montevideo, además, conoció y entró en el pequeño cenáculo formado en torno a Federico García Lorca.

La intimidad con García Lorca fué para el poeta paraguayo algo así como un deslumbramiento. El granadino, rodeado de un grupo de admiradores, solía sentarse a orillas del mar sobre una piedra de la playa arenosa, abrazado a una guitarra andaluza, para improvisar canciones de inspiración popular. A veces Lorca suspendía el rapto de sus improvisaciones acallando la guitarra con un puñado de arena y un súbito golpe de la mano abierta sobre las cuerdas sonoras. Su auditorio entonces estallaba en exclamaciones de entusiasmo.

En Campos Cervera, el elegíaco, quedó imborrable el recuerdo de aquellas horas de embriaguez poética; pero sólo a la muerte de García Lorca iba a dar expresión a aquel recuerdo. Es como si hubiera esperado el instante doloroso propicio, el momento del réquiem:

Federico:

te he visto, aquí, sentado, sobre una piedra negra, frente al mar que amansaba su furor en la playa, mientras el sol pulía tu perfil de gitano sobre el remoto limbo de la tarde dormida. 
Te he visto así: sentado, con la camisa abierta, calcinando tu pecho bruñido de marino; apagando las voces de tu guitarra ardiente con el opaco grito de un puñado de arena. Verde gitano nuestro que maduró la muerte: cuando pasen mil años, junto a esta misma piedra, la misma arena amarga que levantó tu mano aún estará llorando tú nombre amanecido. Cuando te arrodillaste sobre la tierra tuya, el mar, que oreó tu pecho con su aliento de yodo, calló ... Las caracolas rumorosas de música apagaron de pronto sus milenarios cánticos. Granos de terciopelo de la arena marítima; caminos de los vientos que se llevan los sueños, noches enloquecidas por júbilos de mundos, alas que traen y llevan su música encendida; todo: viento y arena, mundos y alas y noches lloran albas de sangre sobre tu nombre claro. Federico: los años han secado tus carnes; en ellas penetraron gusanos de la tierra: pero tu voz remota, poderosa de símbolos, como el mar; no está muerta... Entre un vuelo de albatros y un tumulto de estrellas se volvió al infinito tu fiesta de canciones.

Cuando pasen mil años, junto a esta misma piedra que destacó tu estampa sobre el telón atlántico, aún estaré esperando que otra música análoga taladre el laberinto de cal de mis oídos.

Allí, en Montevideo, a orillas del mar, Campos Cervera halló una voz nueva y tuvo su revelación. $Y$ esto no fué sólo debido a la presencia de Lorca, de quien recibió poderoso influjo, ni a la amistad de otros poetas renovadores de vanguardia. Fué el encuentro con el mar, como él mismo me dijo; fué el descubrimiento de "un mundo de sal" cuyo embrujo presentía obscuramente su corazón mediterráneo. Entonces escribió su "Romance para la gaviota ciega”, primera floración de su poesía de la máscara, hito que marca un nuevo avatar poético, según confesión del escritor.

\section{DesCUBRIMIENTO DEL CAMPO Y DE LA SELVA}

Pasarán algunos años más y el poeta se logrará plenamente en la poesía "de servicio". En Montevideo se había efectuado el descu- 
brimiento del mar. En Peribebuy, Paraguay, 1941, el descubrimiento del campo: su poema "El sembrador". En la misma época, en el Chaco, Campos realiza el descubrimiento de la selva, con su poema "El hachero".

Después de la guerra civil de 1947, se realiza el último descubrimiento: el descubrimiento de la patria, vista ésta desde la perspectiva del destierro. Perseguido, proscripto, Campos Cervera asiste a su última revelación: se siente imperiosamente llamado a ser el cantor de su pueblo, el vindicador de obscuros héroes sacrificados en una lucha que él consideró de la libertad contra la tiranía. $Y$ entonces el poeta cobra total conciencia de sus fuerzas y de su misión, y exclama:

¿Yo soy el Designado!:

... Y aquí estaré por siglos - como un vígía de piedra-, gastando las aldabas de las puertas del día, i hasta que una bandera de olivos y palomas se yerga entre las manos de los muertos vengados!

Pero no nos anticipemos. Violvamos al descubrimiento del campo y de la selva.

MarCelino RUIZ, el sembrador.

Un día de mayo de 1941, en plena campiña de Peribebuy, amaneció en Campos Cervera un hombre nuevo y diferente. Una emoción virgiliana embargaba al poeta bajo el esplendor del sol naciente, mientras marchaba sobre la hierba húmeda de rocío, en pos de Marcelino Ruiz, el sembrador. El poeta estaba descubriendo el campo, es decir, vastos cielos azules, la alegría del sol nuevo, los frescos perfumes de la tierra recién amanecida, la paz, la quietud inefable de una limpia alborada campesina. Y por primera vez el mundo fué para Campos bueno, y por primera vez el sol entró en dorados rayos, en sus sombríos versos:

Es no poco favor el que te debo a tí, Marcelino Ruiz - hombre de dura estampa-, dueño de amanecida visión de lejanías, limpio de pensamiento y entero de conciencia. Por tí fuí a ver la lenta gratitud de los surcos 
y el despertar del grano besado por la tierra. En esta madrugada - que enloquece de júbilo la intacta sinfonía del viento y de los pájaros-. he tomado el camino que lleva hacia tu esfuerzo, para mirar, -vigia y aparcero del alba-, con qué sabiduria preparas tu jornada...

En verdad, Campos Cervera debe un gran favor a Marcelino Ruiz. Gracias al rudo mocetón campesino, el poeta ha inundado su alma de sol y por primera vez ha sentido la alegría del viento $y$ de los pájaros. Gracias a Marcelino Ruiz también, Campos Cervera ha escrito un espléndido poema. Un poema lleno de equilibrio, sobrio, austero, "clásico". No hay en él imágenes de pesadilla, ni comparaciones absurdas, ni alusiones macabras. $Y$ hay, sin embargo, honda emoción, fuerte originalidad y belleza, dentro de la mesura, de la exactitud y de la absoluta inteligibilidad. Los acompasados alejandrinos parecen haber ceñido el ritmo a la lenta marcha del arado:
He visto que la ingente paciencia de los bueyes fué uncida junto al largo tirabuzón del yugo con muy pocas maniobras de tu mano intuitiva. (Una pocas correas, alguno que otro nudo, y la testuz sumisa remolca ya la quilla que engendrará las olas morenas de los surcos).

Tras la comparación del yugo con el tirabuzón -imagen feliz y exacta-, los siguientes versos emplean un lenguaje familiar y casi prosaico que resulta, por contraste, muy poético:

$$
\text { con muy pocas maniobras de tu mano... }
$$

En este tono sencillo el poeta desciende hacia la rústica simplicidad del labriego $y$, al hacerlo, nos trasmite directamente algo de esa augusta sencillez del trabajo de las glebas.

En verdad, el poeta, debe mucho al labriego. ¿Quién si no el campesino "limpio de pensamiento y entero de conciencia" ha lavado sus ojos de imágenes funestas, y quién al corazón del tétrico agonista llevó un haz de dorados resplandores de sol?

El sol baila su alegre festival de reflejos sobre el bruñido acero de la reja, que busca deshacer el caliente corazón de la tierra... 
Por primera vez, lo repito, el sol brilla en los versos de Campos Cervera. Con el descubrimiento del campo, el poeta halló el camino de un nuevo reino poético, menos sombrío y angustioso, donde acaso su espíritu pueda manifestarse más libremente, como desembarazado de las teorías literarias de escuela a que el poeta ha querido someterse, quién sabe si desvirtuado el flujo más espontáneo y entrañable de su inspiración.

LA SELva. Benigno Rojas, el hachero.

En las selvas del Chaco, Campos Cervera realiza otro notable logro poético gracias a Benigno Rojas, el hachero. Aquí, entre los quebrachos centenarios, el poeta no tiene ya la virgiliana serenidad de aquella alborada campesina gozada en compañía de Marcelino Ruiz, el sembrador. Campos retorna a su mundo tétrico y a sus símbolos trágicos. Pero hay, también en este poema, cierto equilibrio "clásico". El alma agónica de Campos necesita salir de sí misma, abandonar el intimismo sombrío, e identificarse con la de otrc hombre, con otra vida, con otro paisaje. Como la mónada de Leibniz, el alma de Campos no tiene ventanas que dejen entrar el sol $\mathrm{Y}$ el poeta necesita sol y oxígeno y la visión de otros panoramas Su paisaje lunar de cal, de sal y de ceniza está pidiendo luz, diafanidades, verdores y espejeos de aguas límpidas. Un cambio, ur haz de nuevas perspectivas, para evitar la monotonia de lo sombríc $y$ de lo luctuoso.

"El hachero" es un poema de estructura armoniosa, de proporciones simétricas. El poeta superrealista que hay en Campos parect que hubiera dejado intervenir al geodesta, a fin de que éste le men. surara con teodolito los territorios poéticos. E1 caos superrealisté se ordena artísticamente. Las imágenes desmesuradas del neorromán tico obedecen a un imperativo de mesura, de rigor, de claridad:

Este es Benigno Rojas: hijo y nieto de hacheros y hachero él mismo. Vino de selvas torrenciales y está como de paso frente a mí, porque siempre camina hacia otras selvas cada vez más lejanas. Le veo marchar llevando sobre la cruz del hombro el fulminante símbolo de su poder: el hacha; y siento que en su pulso rotundo le circula —como en perpetuo flujo-, la fuerza y el coraje. 
En plena selva, el hachero se dispone a iniciar su labor. Los versos de Campos, que ciñeran antes su ritmo a la marcha lenta del arado de Marcelino Ruiz, pronto sonarán al compás de los golpes del hacha del Benigno Rojas, el cual ahora.
respira el sostenido perfume de las hojas y en la solemne cúpula del aire mañanero va eligiendo los cantos de pájaros amigos que regirán la rítmica jornada de sus horas.

El ritmo de los alejandrinos se va haciendo más enérgico y viril, a medida que el poeta se va identificando con el alma primitiva, ruda y fuerte del hachero. Unos compases más, y el verso cerveriano sonará como un hachazo:

Y cuando en rojos círculos los límites del día despuntan, el hachero, poderoso de orgullo, sacude la cabeza para alejar el sueño.

Ya está Benigno Rojas frente al durísimo tronco del primer quebracho - quiebra-hachas-, y ya

lubrica con saliva las palmas de las manos

y comienza su ritmo con taciturna furia.

$\mathrm{Y}$ ahora llegamos al momento en que culmina la lucha del hacha con el tronco casi metálico del quebracho:

Sube el hierro y, de vuelta, su filo incandescente con impacto tremendo se incrusta en la corteza. Regresa diez, cien veces, sobre la misma vértebra, hasta que la garganta desgarrada se rinde...

El que haya visto desplomarse un quebracho en las selvas del Chaco, revivirá intensamente, con el admirable verso de Campos Cervera, el fragoroso derribo del árbol del tanino, gris en la corteza y rojo en las entrañas; el cual, vencido al fin,

entre un furor de gritos se acuesta en la picada.

iVerso maravilloso éste último en que los crujidos de las ramas del árbol que se desploma y choca contra sus compañeros de selva, se convierten en gritos humanos, y en que el gigante vegetal herido, al 
llegar a tierra, ya no se desploma sino que se acuesta como para morir! Y es que el árbol fulminado por el hacha se ha humanizado: sus ramas se truecan en brazos, su fronda en cabellera $y$, dentro de su tronco, hay ahora un corazón que sufre y se desangra por sus vetas:

\author{
Luego vendrán, en lenta sucesión de torturas: \\ el corte de los brazos - la dulce cabellera \\ que en amistad de pájatos vivió quinientos años-. \\ y la final injuria de ser oreado al viento \\ su corazón sangtante, lampiño y desolado. \\ Después, lo que suceda ya no tendrá importancia: \\ viajar, quedarse quieto o arder; será lo mismo. \\ $\mathrm{Ni}$ las nubes del alba, ni pájaros, ni lluvias \\ recostarán su vuelo sobre la ctuz difunta...
}

Adviértase que en el poético antropomorfismo de Campos Cervera, árbol y hombre se identifican en la muerte: ambos tienen su cruz: el hombre, la cruz formada por sus huesos; el árbol, la cruz formada por su tronco y ramas. En este momento del canto, la idea de la muerte vuelve al alma del poeta y se apodera sombriamente de ella. E1 poeta convierte su himno al hachero en elegía al quebracho y se despide del árbol caído, con un bellísimo réquiem. La naturaleza toda se anima y angustia y llora. La tierra, el humus, cósmicamente sacudido,
1lora, junto a las rojas cicatrices y tiende sobre las venas rotas sus manos de substancias para que en los futuros milenios no perezcan los encendidos brotes que duermen bajo tierra...

El poeta abandona el quebracho caído y sigue en pos del hombre, de Benigno Rojas, cuya vida es un vía crucis a través de la selva titánica. El hachero, explotado por los latifundistas, es víctima de una atroz tiranía. Al cabo de semanas y semanas de trabajo agobiador, los explotadores del hachero

abren, al fin, la puerta blindada y con sus garras de pájaros nocturnos - como quien da la vida-. su pagan dan al hijo diurno de la selva...

El poema decae un tanto en intensidad y belleza, al convertirse en grito de reivindicación social. Este es un descenso artístico en 
que incurre el fervor "projimista" del poeta. Pero en seguida vuelve a remontar el vuelo poético el cantor del hachero:

Después ... Es el camino. Los puertos, las nostalgias

de amor, y la guitarra y el cuchilló y la caña.

- Lento o precipitado rodar hacia el agobio-.

Siempre es igual: un día, de nuevo hacia la noria;

el hacha compañera sobre la cruz del hombro

y un infinito sueño colgado de los párpados...

$Y$ al fin, llega otro día en que a Benigno Rojas "vieja ley de cuchillos lo llamó por su nombre - sin darle tiempo alguno para mirar el ceño - del que lo ató a la tierra del canto y del gusano"-. Y muere asesinado el hercúleo atleta de la selva. La última parte del poema es una espléndida elegía:

Un sueño de guitarras, de puñales y música le completó la muerte que ya llevaba dentro, y entre la luz de sombras, de su fin reiterado, sus turbios ojos vieron levantarse, muy lejos, sobre un alto horizonte de oxidados contornos una cruz de quebracho de brazos encendidos -velando el firme sueño-, y en ella, recostada, sosteniendo el sombrero y en actitud de espera-. el hacha compañera de hazañoso recuerdo...

Descubridor de la selva, Campos Cervera, poeta de la muerte, se aleja de los árboles centenarios, después de plantar una transfigurada cruz de quebracho sobre la tumba de Benigno Rojas, el hachero.

\section{LA POESÍA DEL DESTIERRO}

La guerra civil paraguaya de 1947 terminó en el mes de agosto de ese año, con la derrota de los insurgentes. Estos, en un núcleo inicial de tropas aguerridas conducidas por veteranos del Chaco, se habían sublevado en la ciudad norteña de Concepción, a orillas del río Paraguay. Pronto el movimiento se hizo popular en la República, y lo que comenzó siendo una cuartelada dividió a la nación en dos bandos. Los partidos de la oposición se adhirieron a la revuelta. En Asunción, mientras tanto, un gobierno fuerte y enérgico actuó con rapidez. Movilizó todo un cuerpo de ejército y a bordo 
de una flotilla de cañoneros lo envió río arriba, para poner cerco a la ciudad rebelde. Los revolucionarios se defendieron valerosamente, repelieron victoriosamente los ataques gubernamentales y tras pacientes preparativos decidieron llevar a cabo un plan audaz, para neutralizar su inferioridad numérica. Una noche abandonaron la ciudad sitiada y sigilosamente se embarcaron en lanchones protegidos a babor y estribor por gruesos troncos de quebracho, detrás dc los cuales emplazaron ametralladoras y morteros. Navegaron en las tinieblas de la noche invernal, hasta llegar al puerto donde la flotilla gubernamental estaba fondeada, a pocos kilómetros de Concepción, y la tomaron al abordaje. Una vez dueños de buques veloces y bien artillados, zarparon con rumbo a Asunción. Atrás quedaron las tropas sitiadoras, separadas de la capital por una enorme distancia, sin caminos de agua ni de tierra.

La revolución parecía triunfante. Así lo proclamaba la radioemisora rebelde, en discursos patrióticos, escuchados en toda la República. A la cabeza de tropas fogueadas, los jefes revolucionarios caían sobre una capital que creían defendida tan sólo por fuerzas policiales armadas de fusiles. Pero cuando llegaron a los aledaños de Asunción los rebeldes fueron recibidos con un espeso fuego de toda suerte de armas de guerra. La capital estaba fuertemente defendida. El gobierno creó batallones de milicianos fanáticamente adictos. Los esfuerzos revolucionarios se estrellaron entonces con una inflexible voluntad, con fuerzas que crecían con el transcurso de los días. Viejos odios políticos se habían enconado hasta el paroxismo. Los gubernamentales eran una fuerza homogénea, tanto en lo político como en lo militar; los revolucionarios, una coalición de partidos. Ya se suscitaban diferencias entre los últimos cuando, a marchas forzadas, abriendo caminos, llegaron las tropas del gobierno que habían sido dejadas atrás en el norte. Cogidos entre dos fuegos, los rebeldes fueron aniquilados. Cesó el fuego y comenzaron las proscripciones y los encarcelamientos. Se produjo una emigración en masa; las cárceles se llenaron de presos, suspendidas las garantías constitucionales. Mientras en el extranjero los fugitivos buscaban el pan del destierro, enflaquecidos y desmoralizados, en las cárceles la situación era aún peor para los vencidos. La severidad de las represalias fué tal, que el presidente de la Corte Suprema en persona -dirigente del partido triunfante-, protestó ante sus propios correligionarios 
y se echó a la calle a la cabeza de una manifestación de madres, hermanas y esposas que fué a pedir al pie de los balcones de palacio la libertad de los presos.

Campos Cervera emprendió en agosto de 1947, por segunda vez, el camino del exilio. $Y$ fué en tierra argentina, aturdido aún por el estruendo de la pólvora, cuando el poeta se sintió llamado a elevar un canto en que cupiera toda la angustia de la derrota. El había sido testigo del cruento drama de su pueblo. No lejos de su casa había rugido la batalla:

Yo estaba en el costado de la furia
cuando ellos manejaban las aristas del trueno;
los he visto poblando de centellas azules
las heladas esquinas de la noche...

Así el poeta evoca las horas nocturnas de la lucha en las calles de su ciudad, al fin del invierno. La voz todavía le tiembla húmeda de lágrimas, al cantar la patria cuya tierra no pueden pisar sus pies errantes de proscripto:

Quise de tí tu noche de azahares;

quise tu meridiano caliente y forestal;

quise los alimentos minerales que pueblan

los duros litorales de tu cuerpo enterrado,

y quise la madera de tu pecho.

Eso quise de Tí

-Patria de mi alegría y de mi duelo-,

¡Eso quise de Tí!

No tengo ya el remoto jazmín de tus estrellas

ni el asedio nocturno de tus selvas.

Nada: ni tus días de guitarra y cuchillos,

ni la desvanecida claridad de tu cielo...

Pero así, caminando, bajo nubes distintas,

sobre los fabricados perfiles de otros pueblos,

por entre soledades invencibles,

o por ciegos caminos de música y trigales,

descubro que te extiendes largamente a mi lado

con tu martirizada corona y con tu limpio

recuerdo de guaranias y naranjos.

Estás en mí: caminas con mis pasos,

hablas por mi garganta; te yergues en mi cal

y mueres, cuando muero, cada noche. 
Este descubrimiento de la patria que se le hace presente viviendo, sufriendo y muriendo con él, hace que el poeta, al levantar su canto, se sienta como agigantado. Le ha llegado la hora de ser el vate de su pueblo: él debe henchir su corazón, para que en él se refugien todos los dolores y se enciendan también las llamas de la esperanza. $\mathrm{Y}$ su estatura crece; el poeta se titaniza:

IYo sé que estoy llevando tu Raíz y tu Suma

sobre la cordillera de mis hombros ....!

Los hombros del poeta que eran cruz pesadisima se han vuelto cordillera, porque hay que cantar a esos héroes anónimos que en las batallas perdidas

Simplemente

bajaron a morir para dejarnos

otro tiempo más limpio y otra tierra más clara,

algún laurel más alto y un aire más sencillo...

- acaso otra manera de abrir una ventana

para llamar el día del Hombre Venidero...

$\mathrm{Y}$ porque hay que lanzar un vaticinio de esperanza en el triunfo final de los ideales del poeta y de todos los vencidos:

Yo lo proclamo desde el hondo reverso de esta paz de cadáveres:

Porque no está vencida la fe que no se rinde ni el amor que defiende la redonda alegria de su pequeña lámpara, tras el pecho del hombre...

... Yo sé que en la mañana del tiempo señalado todos los calendarios y campanas

llamarán a los bijos de este día.

Y ellos vendrán, cantando, con su misma bandera, con su mismo fusil recuperado; vendrán con esa misma sonrisa transparente que no tuvieron tiempo de enterrat.

Y el poeta quiere que su voz resuene en toda América y lanza un llamamiento a los poetas "de América y del mundo", a fin de que ellos vengan a "palpar el sudario de su pueblo" que ha de alzar la cabeza en una resurrección a la libertad y de la justicia:

Acércate a nosotros. Pablo Neruda, hermano, con tu presencia andina, con tu voz magallánica, 
con tus metales ciegos y tus hombros maritimos...

¿Ven, Nicolás Guillén,

desde tu continente de tabaco y azúcar,

y con esa segura nostalgia de tus labios

ponle un exacto nombre a esta agonía!

IY tú, Rafael Alberti - marinero en desvelo-.

pastor de los olivos taciturnos de España...

dibújanos el mapa

de estos desamparados litorales de muerte!

Así, Hérib Campos Cervera, poeta de la muerte, tétrico y desesperanzado, ha hallado en los caminos del destierro la música de una poesía más vigorosa y luminosa. $Y$ acaso, y para siempre, en su páramo de cal, de sal y de ceniza brote un manantial de aguas de esperanza y de luz y florezcan rosas de vida donde sólo se abrían los lirios de la muerte.

\section{Hugo Rodríguez Alcalá, University of Wisconsin, Madison, Wisconsin.}

\section{NOTAS}

1 Hérib Campos Cervera pertenece a una familia hispano-paraguaya de intelectuales y artistas. Su abuelo paterno fué el periodista y profesor español Cristóbal Campos y Sánchèz; su abuelo materno, el erudito extremeño Nicolás Díaz-Pérez, autor del Diccionatio biográfico y bibliográfico de extremeños ilustres. El pađre del poeta fué un fogoso periodista y poeta, director y dueño del diario La Verdad. Andrés Campos Cervera, tío paterno del poeta, es el más notable de los artistas plásticos paraguayos: gran ceramista, pintor, grabador y escultor. Viriato Díaz-Pérez, tío materno del poeta, director de la Biblioteca Nacional de Asunción, hombre de vasta cultura literaria y científica, ha sido maestro de las generaciones intelectuales paraguayas en los últimos cincuenta años. Véase Carlos R. Centurión, Historia de las letras paraguayas, (Buenos Aires. Editorial Asunción, 1948), pp. 210, 304-307.

2 "surrealisM, n. Pure psychic automatism" - define André Bréton-" "by which it is intended to express, verbally, in writing, or by other means, the real process of thought. Thought's dictation, in the absence of all control exercised by the reason and outside all aesthetic or moral preoccupations". Ver André Breton, ¿What is suttealism?, (London. Faber \& Faber Limited, 1934), p. 59. Consúltese el notable libro de Georges E. Lemaître, From cubism to sutrealism in French Litetature. (Cambridge, Mass. Harvard University Press, 1941). 
3 "Write quickly" -aconseja André Breton-, "without any previously chosen subject, quickly enough not to dwell on, and not to be tempted to read over; what you have written". Ver André Breton, op. cit., p. 62. En el prefacio escrito al Essai d'explication du Cimetière Matin, de M. G. Cohen, Paul Valéry escribió estas palabras que expresan su idea favorita sobre la creación poética: "On en arrive au travail pout le travail. Aux yeux de ces amateurs d'inquiétude et de perfection", - el caso ejemplar de los cuales es el mismo Valéry-, "un ouvrage n'est jamais achevé, - mot qui pour eux n'a aucun sens, - mais abandoné; et cet abandon, qui le livre aux flammes ou au public (et qu'il soit l'effet de la lassitude ou de l'obligation de le livrer), leur est une sorte d'accident, comparable à la rupture d'une réflexion, que la fatigue, le facheux, ou quelque sensation viennent tendre nule". Ver Paul Valéry, Vatiété III, (Paris: Gallimard, 1946), p. 56. Los superrealistas difieren de la manera más enfática. Véase cómo A. Breton y Paul Eluard refutan violentamente a Valéry y otros "amateurs de perfection": "un poème est toujours achevé - il ne peut être à la merci de l'accident qui le termine, c'est-à-dire qui le donne au public.

$\mathrm{Ni}$, comme le croient les cochons, de la lassitude, de la demande de l'editeut, ni de la 'pousée' d'un autre poème." Ver A. Breton y P. Eluatd, Notes sut la poésie. (Paris. Editions G. L. M., 1936), p. 23.

4 Véase en Breton, ¿What is surtealism?, cómo se puede ser superrealista de numerosas maneras: Heráclito es superrealista en dialéctica; Lulio, en la definición: Swift, en la malicia; Baudelaire, en la moral; Rimbaud en la vida y otras cosas... Campos Cervera se aparta de Breton y otros superrealistas en cuanto a la posición con respecto al materialismo histórico. Nuestro poeta no es marxista, como tampoco lo es, por ejemplo, Aleixandre. Para un estudio sobre las relaciones del superrealismo y el marxismo, véase el libro de $A$. Breton, Position politique du sutréalisme, (Paris. Editions du Sagitaire, 1935), pp. 78 y siguientes. También véase Herbert Read, Sutrealism, (London. Faber $\&$ Faber, 1936), pp. 42 y 100, especialmente.

5 Carta personal de Hérib Campos Cervera del $1^{\circ}$ de enero de 1949. El término projimidad será explicado más adelante en este trabajo.

6 Véase la importancia del papel desempeñado por Campos Cervera en la renovación poética del Paraguay en Walter Wey, La poesia paraguaya, (Montevideo: Biblioteca Alfar, 1951), pp. 86-87.

7 Uno de estos discipulos de Campos Cervera, el adolescente Elvio Romero, inspiró a Rafael Alberti un sentido romancillo publicado en Cuadernos Ameticanos, año IX, vol. LI, de mayo-junio de 1950.

8 De mi artículo "Sobre la poesía y lo poético", La Tribuna, 5 de julio de 1946 .

9 Véase Sinforiano Buzó Gómez, Indice de la poesía pataguaya, (Asunción-Buenos Aires: Editorial Tupá, 1943), p. 309. 
10 Algunas frases que Campos solía citar a menudo de la obrita de Rilke, transcribo aquí, de la versión francesa de Bernard Grasset y Rainer Biemel: "Une oeuvre d'art est bonne quand elle est née d'une nécessité. C'est la nature de son origine qui la juge... Monsieur, n'ai-je pu vous donner d'autre conseil que celui-ci: entrez en vous-même, sondez les profondeurs où votre vie prend sa source. C'est là que vous trouverez la réponse a la question: devrez-vous créer?" ... (Il suffit, selon moi, de sentir que l'on pourrait vivre sans écrire pour qu'il soit interdite d'écrire)". Rainet-Maria Rilke, Letttes a un jeune poete, (Paris: Bernard Grasset, 1937), pp. 21-22.

11 Hay una sola excepción, dentro de la obra cerveriana, a este sombrío pesimismo en el poema "El Sembrador", que se comentará más adelante.

12 Hérib Campos Cervera, Ceniza tedimida, (Buenos Aires. Editorial Tupá, 1950).

13 Véase el citado ibro de Walter Wey, pp. 55 y siguientes.

14 Véase mi librito Alejandto Guanes, vida y obra, (Nueva York. Hispanic Institute in the United States, Columbia University, 1951). 
